\title{
Efficiency Study Comparing Two Helicopter Planetary Reduction Stages
}

Timothy L. Krantz and Robert F. Handschuh

Propulsion Directorate

U.S. Army Aviation Research and Technology Activity-AVSCOM Lewis Research Center

Cleveland, Ohio

Prepared for the

26th Joint Propulsion Conference

cosponsored by the AIAA, SAE, ASME, and ASEE

Orlando, Florida, July 16-18, 1990 


\title{
EFFICIENCY STUDY COMPARING TWO HELICOPTER PLANETARY REDUCTION STAGES
}

\author{
Timothy L. Krantz and Robert F. Handschuh \\ Propulsion Directorate \\ U.S. Army Aviation Research and Technology Activity - AVSCOM \\ Lewis Research Center \\ Cleveland, Ohio 44135
}

\section{Abstract}

A study was conducted to compare the efficiency of two helicopter transmission planetary reduction stages. Experimental measurements and analytical predictions were made. The analysis predicted and experiments verified that one planetary stage was a more efficient design due to the type of planet bearing used in the stage. The effects of torque, speed, lubricant type, and lubricant temperature on planetary efficiency are discussed.

\section{Int roduction}

One important factor considered in the design of a power transmission is its mechanical efficiency. Helicopter transmissions are extremely efficient, typically above 95 percent for the complete main rotor transmission. From the viewpoint of providing power to the helicopter rotor, the benefit from slightly improving the efficiency of an already efficient transmission may seem trivial, but there are other benefits. Mechanical losses must be dissipated as heat, and an improvement in efficiency will allow the use of smaller, lighter weight cooling systems. In this way improving the efficiency increases payload or aircraft range.

The power loss of gears, bearings, and transmissions have been studied by many investigators.1-7 Analytical methods have been developed $4-7$ to study the influence of gear design parameters on efficiency and to provide a tool for transmission design. The objectives of the work presented here were to provide experimental evidence of the validity of the analytical method, to study the effects of operating conditions on efficiency, and to compare the efficiency of two planetary stage designs.

\section{Experimental Method}

Test Rig, Instrumentation, and Data Acquisition System

The two planetary stages studied were taken from two versions of the U.S. Army's $0 \mathrm{H}-58$ helicopter main rotor transmission. This transmission has a reduction ratio of 17.44 overall, with the planetary stage contributing a ratio of 4.67 . The two planetary stages are described in Table 1 . The differences between the two stages are that one has three planets and uses double row spherical planet bearings while the other has four planets and uses cylindrical planet bearings (Fig. 1). The planet gears of the three-planet stage are mounted on a post cantilevered from the carrier. The planet gears of the four-planet stage, however, are mounted on posts that are supported on both ends by the carrier and a retainer plate. This arrangement is used on the four-planet stage to minimize the misalignment of the planet gears and cylindrical bearings .
The planetary stages were tested in a rig (Fig. 2) that used a regenerative-torque, back-toback configuration where a test and a slave section were loaded against each other by applying hydraulic pressure to a rotating torque actuator. The rotating torque actuator twisted the slave section sun gear relative to the high speed shaft to produce the loop torque. The drive motor rotated the high speed shaft and supplied power to overcome rig and test hardware losses. The entire rig and its lubrication system were insulated during testing so that test temperatures could be reached in a reasonable amount of time. Figure 2 shows the rig with the three-planet stage in the test section and the four-planet stage in the slave sec$t i o n$ for purposes of illustration only. During testing, identical stages were used in both the test and slave sections.

Each planetary stage was lubricated by separate, identical systems. Each system included a number of manifolds through which flow was dispersed to individual areas. Each lubrication system was instrumented with turbine flowmeters, thermocouples, and pressure transducers.

The input torque to the rig was measured by a commercially available transformer coupled torquemeter. The torque carried by the low speed shaft and by the high speed shaft were measured with strain gages on the shafts arranged in a full Wheatstone bridge. The Wheatstone bridge conditioning circuits rotated with the shafts, and the output from the circuits was transmitted across sliprings. The output signals from the torque measuring instruments was low-pass filtered to remove frequencies above $0.2 \mathrm{~Hz}$.

Data were collected and stored by a remote mainframe computer to provide a chronological history of the test. This enabled post-test processing of key data. All data channels were updated every 2 sec while tests were being run.

A more detailed description of the test rig, instrumentation, and calibration method is contained in Ref. 3 .

\section{Test Procedure and Data Reduction}

A total of 254 tests were conducted. The variables altered during the test program were rotational speed, load, lubricant flow rate, lubricant inlet temperature, lubricant pressure, and lubricant type. The maximum test conditions for sun-gear speed and sun-gear torque for the four-planet planetary stage were $1622 \mathrm{rpm}$ and $1840 \mathrm{Nm}$ (16 $300 \mathrm{in.-lbf})$, respectively. The maximum test conditions for the three-planet planetary stage were $1620 \mathrm{rpm}$ and $1405 \mathrm{Nm}$ 
(12 450 in.-lbf). Therefore, at the maximum test condition for both stages, each planet carries approximately $465 \mathrm{Nm}$ (4120 in.-lbf) torque load.

For each test the first variable to be stabilized was the lubricant inlet temperature. Once the required lubricant inlet temperature was reached, the lubricant flow rate, the shaft rotational speed, and the load were set. The rig was then run at these conditions for at least $10 \mathrm{~min}$ in order to reach steady state before any data were taken. Bearing temperatures and torques were stable typically after $5 \mathrm{~min}$. For each test at least five sets of data were taken. Each set of data consisted of five consecutive

2 sec scans averaged to produce one set. Thus, at least 25 scans were averaged for each test. Inspection of the data after the testing showed no significant changes in the raw data between the five sets of data taken at the same condition. The entire cycle was repeated for each test condition.

To measure the losses based on a given set of conditions, the torque required to drive the complete system was monitored. The torque to rotate the test planetary section, because of its losses, was assumed to be half of the torque remaining after the rig tare losses were subtracted from the total drive motor torque. An equal split of the losses was assumed because, except for direction of rotation, the test and slave planetary sections were identical in their gear and bearing configuration, lubrication flow rate, lubricant type, and lubricant inlet temperature for all tests conducted.

Operating efficiency $\eta$ was computed from the following equation:

$$
\eta=\frac{\left[\mathrm{P}_{\text {in }}-0.5\left(\mathrm{P}_{\mathrm{DM}}-\mathrm{P}_{\text {tare }}\right)\right] \times 100}{\mathrm{P}_{\mathrm{T}_{\text {in }}}}
$$

where ${ }^{P_{T}} \mathrm{~T}_{\text {in }}$ is the total input power to the test planetary section. This equals the loop power on the high-speed shaft plus the drive motor power minus the input stub shaft losses. The net loss of the test and slave planetary sections equals the drive motor power minus the facility tare losses ( $\left.\mathrm{P}_{\mathrm{DM}}-\mathrm{P}_{\text {tare }}\right)$.

An uncertainty analysis ${ }^{9}$ was performed on this equation. The accuracy of the result is a function of the test conditions and the uncertainties in the measured quantities. For this equation the worst situation is when the test rig torque is low ( 10 percent of full torque) and the inaccuracy of the measuring instruments is high. Two example cases (Table 2) show that the assumed accuracy along with the test conditions can affect the uncertainty in the measured efficiency.

The facility tare losses are those due to components of the test rig (Fig. 2) other than the gear meshes and planet bearings. These facility tare losses were determined experimentally by a set of special tests where the support shafting and components were rotated without the gears meshing. The facility was operated in this manner over the range of operating speeds and temperatures that were used during the testing reported here, and the facility tare loss was measured. Details of the special test procedure and test results are reported in Ref. 3 .

\section{Analytical Method}

To model the efficiency of a planetary gear train, many sources of power loss must be considered. The losses from meshing gears include sliding and rolling friction losses, windage, and lubricant displacement losses. ${ }^{4}$ The planet bearings losses also contribute to the total planetary system loss. The sum of these loss components was used to predict the planetary stage efficiency.

The computer program SPHERBEAN10,11 was used to calculate losses from the spherical bearings, while the program PLANETSYS 12 was used to calculated losses from the cylindrical planet bearings. Two other computer programs, EXTERN and INTERN, 4 were used to predict gear mesh sliding, rolling and windage losses for external and internal gear meshes, respectively. These two programs are based on the methods of Refs. 5 to 7 . The calculations within these gear mesh programs for power loss due to sliding include a model for the coefficient of friction based on the data of Ref. 8 . The power loss due to oil, trapped by gear teeth, being displaced from the gear mesh was calculated using a model that accounts for the power to accelerate the oil and displace it from the mesh. The analytical methods are described in more detail in Refs. 3 and 4.

The gear geometry data used in the analysis are shown in Table 1, and the lubricant properties used are shown in Table 3 .

\section{Results and Discussion}

The previously described procedure was used to calculate the efficiency for each of the 254 test conditions. Complete tables of the experimental results are given in Refs. 3 and 4 . Typical results are presented and discussed in this paper.

The two lubricants used in the parametric tests were the oils $\mathrm{E}$ and $\mathrm{K}$ from Ref. 1 (see Table 3 ). Lubricant $\mathrm{E}$ is a formulated gear lubricant (dibasic acid ester), and lubricant $K$ is a turbine engine oil (mixture of 99 percent PE (pentaerythritol ester) and 1 percent DPE (dipentaerythritol ester). The highest efficiency ( 99.83 percent) was measured while testing the three-planet stage with lubricant $K$ and operating at the highest speed, lowest load, and lowest lubricant inlet temperature tested. The lowest efficiency ( 98.64 percent) was measured also while testing the three-planet stage but with lubricant $\mathrm{E}$ and operating at the lowest speed, highest load, and highest lubricant inlet temperature tested. For the three-planet stage, the efficiencies measured while testing at full power ranged from 99.25 to 99.41 percent depending on the lubrication parameters. For the four-planet stage, the efficiencies measured while testing at full power ranged from 99.44 to 99.60 percent depending on the lubrication parameters. 
All of the parameters varied during the tests affected the planetary stage efficiency. Some parameters had a much greater effect than others. Following is a discussion of typical results presented in Figs. 3 to 7

The effect of speed on planetary stage efficiency is presented in Fig. 3. The planetary stage efficiency is plotted as a function of torque for different speeds. For nearly all conditions tested, the efficiency increased with increasing speed. (Trends at very low power levels sometimes deviated from typical results.)

The effect of lubricant inlet temperature on efficiency is presented in Fig. 4. The data shown is for testing with lubricant E. Results from the four-planet stage testing show efficiency increasing with increasing temperature. This is an expected result since the lubricant viscosity decreases with increasing temperature. However, the results from the three-planet stage testing show the efficiency at $99^{\circ} \mathrm{C}\left(210^{\circ} \mathrm{F}\right)$ lubricant inlet was less than at $82{ }^{\circ} \mathrm{C}\left(180{ }^{\circ} \mathrm{F}\right)$. The data of Ref. 1 showed that the efficiency of a complete helicopter transmission operating with lubricant $E$ decreased with increasing temperature. The most efficient operating temperature of a planetary stage depends on the type of lubricant used and the design. Temperature dependent properties of lubricants other than viscosity affects the efficiency of a gear train.

The effect of lubricant type on efficiency is presented in Fig. 5. The four-planet stage was more efficient operating with lubricant E compared to lubricant $K$. However, the three-planet stage was more efficient operating with lubricant $K$ compared to lubricant $E$. This difference is related to the greater amount of sliding that occurs in the three-planet stage spherical bearings compared to the four-planet stage cylindrical bearings 13 and the traction properties of the lubricants.

Figures 3 to 5 together illustrate two more important trends. In general, efficiency decreased with increasing torque except at very low torques where no load losses begin to dominate. Also, the efficiency of the four-planet stage was significantly greater than that of the three-planet stage. The discussion that follows on the analytical results will explain the reason for the differences.

Typical analytical results predicting the efficiency of the two stages are shown in Figs. 6 and 7 along with the experimental results. For most conditions tested the analysis predicted a higher efficiency than was measured. Also the correlation between experiment and analysis was best for the data at $60^{\circ} \mathrm{C}\left(140^{\circ} \mathrm{F}\right)$ lubricant

temperature and high torque. The experiments and analysis showed the same trends of decreasing efficiency with increasing torque and of the fourplanet stage having a greater efficiency than the three-planet stage.

The rationale why the four-planet stage is more efficient than the three-planet stage is illustrated by Fig. 8. An analytical prediction of the power loss per planet for each stage is shown. The torque carried per planet is approximately the same for both stages. The total power loss is shown as the sum of sun-planet mesh. planet-ring mesh, and planet bearing losses. The large power loss from the spherical bearings used in the three-planet stage was predicted and verified by experiments. The extra power required to operate the spherical bearings in the three-planet stage compared to the cylindrical bearings depended on the operating conditions. Both analysis and experiment showed that approximately an additional $0.2 \mathrm{~kW}(0.26 \mathrm{hp})$ power per bearing was required. The reason for the additional power required is the great amount of sliding that occurs in double row sperical bearings.

\section{Summary of Results}

A study was done to compare the efficiency of two helicopter transmission planetary reduction stages. The planetary stages studied were from two versions of the U.S. Army's $\mathrm{OH}-58$ helicopter transmission. The gears used in the two stages are of the same design; however, one stage has three planets and uses spherical planet bearings while the other has four planets and uses cylindrical planet bearings. Both experiments and analysis were done to study the efficiency of these two stages, and the results of these studies were compared. The following results were obtained:

1. The analysis predicted that the stage using cylindrical bearings would have a much better efficiency than the stage using spherical bearings. The experiments confirmed the prediction that the spherical bearings require much more power to operate than the cylindrical bearings, approximately $0.2 \mathrm{~kW}(0.26 \mathrm{hp})$ per planet.

2. The experiments showed that for both stages efficiency increased with increasing speed.

3. Experiments were done using two different oils. The stage using cylindrical bearings was more efficient while operating with lubricant E, a formulated gear lubricant. However, the stage using spherical bearings was more efficient while operating with lubricant $K$, a turbine engine oil.

4. The most efficient operating temperature for the gear train depends on the lubricant being used. For lubricant E efficiency decreased with increasing temperature. Lubricant $K$ showed the opposite trend.

5. Both the experiments and analys is showed that the efficiency of the stages decreased with increasing torque.

6. In general, the analysis predicted higher efficiencies than were measured. The correlation between experiment and analysis was best at the operating condition of the lowest oil inlet temperature studied and at high torque.

\section{References}

1. Mitchell, A.M. and Coy, J.J., "Lubricant Effects on Efficiency of a Helicopter Transmission," Problems in Bearings and Lubrication, AGARD CP-323, AGARD, Paris, France, 1982 , pp. 20-1 to 20-16 (NASA TM-82857) . 
2. Mizutani, H., Isikawa, Y., and Townsend, D.P. "Effects of Lubrication on the Performance of High Speed Spur Gears," NASA TM-101969, 1989.

3. Handschuh, R.F. and Rohn, D.A., "Efficiency Testing of a Helicopter Transmission Planetary Reduction Stage," NASA TP-2795, 1988.

4. Krantz, T.L., "Experimental and Analytical Evaluation of the Efficiency of a Helicopter Planetary Stage," to be published, 1990.

5. Anderson, N.E. and Lowenthal, S.H., "SpurGear-System Efficiency at Part and Full Load," NASA TP-1622, 1980.

6. Anderson, N.E., Lowenthal, S.H., and Black, J.D., "An Analytical Method To Predict Efficiency of Aircraft Gearboxes," AIAA Paper 84-1500, June 1984. (NASA TM-83716).

7. Anderson, N.E. and Lowenthal, S.H., "Efficiency of Nonstandard and High Contract Ratio Involute Spur Gears," Journal of Mechanisms, Transmission, and Automation in Design, Vol. 108, No. 1, Mar. 1986, pp. 119-126

(NASA TM-83725).

8. Tevaarwerk, J.L., "Constitutive Modelling of Lubricants in Concentrated Contacts at High Slide to Roll Ratios," IR-4, Transmission Research Inc., Cleveland, $\mathrm{OH}, 1985, \mathrm{NASA}$ CR-175029.

TABLE 1. - PLANETARY GEAR TRAIN HARDWARE USED IN TEST AND SLAVE SECTIONS [Planetary reduction ratio: 4.667 .]

(a) Gear data

\begin{tabular}{|l|c|c|c|c|r|r|}
\hline Gear & \multirow{2}{*}{$\begin{array}{c}\text { Number of } \\
\text { teeth }\end{array}$} & \multirow{2}{*}{$\begin{array}{c}\text { Module, } \\
\end{array}$} & & \multirow{2}{*}{$\begin{array}{c}\text { Diametral } \\
\text { pitch, } \\
\text { in. }\end{array}$} & \multirow{2}{*}{$\begin{array}{c}\text { Pressure } \\
\text { angle, } \\
\text { deg }\end{array}$} & \multicolumn{2}{|c|}{ Pitch diameter } \\
\cline { 5 - 7 } & & & & & \multicolumn{1}{|c|}{ in. } \\
\hline Sun & 27 & 2.868 & 8.857 & 24.6 & 77.4 & 3.048 \\
Planet & 35 & 2.868 & 8.857 & 24.6 & 100.4 & 3.048 \\
Ring & 99 & 2.778 & 9.143 & 20.2 & 275.0 & 10.828 \\
\hline
\end{tabular}

(b) Bearing data

\begin{tabular}{|l|c|c|c|c|c|c|c|c|}
\hline & \multirow{2}{*}{ Type } & \multicolumn{2}{|c|}{$\begin{array}{c}\text { Inside } \\
\text { diameter }\end{array}$} & \multicolumn{2}{|c|}{$\begin{array}{c}\text { Outside } \\
\text { dianeter }\end{array}$} & \multicolumn{2}{|c|}{$\begin{array}{c}\text { Roller } \\
\text { diameter }\end{array}$} & \multicolumn{2}{c|}{$\begin{array}{c}\text { Vumber of } \\
\text { rollers } \\
\text { per row }\end{array}$} \\
\cline { 2 - 8 } & & mm & in. & mm & in. & mn & in. & \\
\hline $\begin{array}{l}\text { 3-planet } \\
\text { stage }\end{array}$ & $\begin{array}{l}\text { Double row } \\
\text { spherical }\end{array}$ & 31.8 & 1.25 & 76.2 & 3.00 & 13 & 0.512 & 12 \\
\hline $\begin{array}{l}\text { 4-planet } \\
\text { stage }\end{array}$ & Cylindrical & 46.5 & 1.83 & 68.5 & 2.70 & 11 & 0.433 & 13 \\
\hline
\end{tabular}

9. Dally, J.W., Riley, W.F., and McConnell, K.G., Instrumentation for Engineering Measurements. John Wiley \& Sons, Inc., 1984, pp. 543-545.

10. Kleckner, R.J., Pirvics, J., and Ragen, M.A. "Spherical Roller Bearing Analysis, SKF Computer Program SPHERBEAN. Volume 1: Analysis," NASA CR-167858, 1982.

11. Kleckner, R.J., Dyba, G.J., and Ragen, M.A., "Spherical Roller Bearing Analysis, SKF Computer Program SPHERBEAN. Volume 2: User's Manual," NASA CR-167859, 1982.

12. Hadden, G.B., et al., "PLANETSYS: A Computer Program for the Steady State and Transient Thermal Analysis of a Planetary Power Transmission System: User's Manual," SKF-AT81D044, SKF Technology Services, King of Prussia, PA, 1981, NASA CR-165366.

13. Kleckner, R.J. and Pirvics, J., "Spherical Roller Bearing Analysis," Journal of Lubrica$\mathrm{t} i$ on Technology, Vol. 104, No. 1, Jan. 1982, pp. 99-108
TABLE II, - RESULTS FROM UNCERTAINTY ANALYSIS

\begin{tabular}{|c|c|c|c|c|}
\hline \multirow[t]{2}{*}{$\begin{array}{l}\text { Test measurements } \\
\text { and calculating } \\
\text { facility losses }\end{array}$} & \multicolumn{2}{|c|}{$\begin{array}{l}\text { Test condition } \\
\text { or calibration } \\
\text { value }\end{array}$} & \multirow{2}{*}{$\begin{array}{c}\text { dssumed } \\
\text { accuracy, } \\
\text { percent } \\
(+1-)\end{array}$} & \multirow{2}{*}{$\begin{array}{c}\text { Encertainty } \\
\text { in efficiency } \\
\text { calculation, } \\
\text { percent } \\
(+1-)\end{array}$} \\
\hline & $\mathrm{Nm}$ & in. Ibf & & \\
\hline \multicolumn{5}{|c|}{ Case 1: 100 percent torque; high accuracy } \\
\hline $\begin{array}{l}\text { High speed shaft } \\
\text { torque }\end{array}$ & 1410 & $12+50$ & 1.0 & \multirow{4}{*}{0.011} \\
\hline $\begin{array}{l}\text { Drive motor input } \\
\text { torque }\end{array}$ & 24.5 & 217 & 1.2 & \\
\hline $\begin{array}{l}\text { Facility tare } \\
\text { loss }\end{array}$ & 2.4 & 21.2 & + & \\
\hline Input shaft loss & 0.9 & 8 & 4 & \\
\hline $\begin{array}{l}\text { High speed shaft } \\
\text { torque }\end{array}$ & 165 & 1460 & 4 & \multirow{4}{*}{0.072} \\
\hline $\begin{array}{l}\text { Drive motor input } \\
\text { torque }\end{array}$ & 5.0 & 44.2 & 10 & \\
\hline $\begin{array}{l}\text { Facility tare } \\
\text { loss }\end{array}$ & 2.4 & 21.2 & 4 & \\
\hline Input shaft loss & 0.9 & 8 & 4 & \\
\hline
\end{tabular}

TABLE IIL - PROPERTIES USED FOR ANALYSIS ANI CALCULATIONS

\begin{tabular}{|c|c|c|c|c|c|c|c|c|c|c|c|c|}
\hline \multirow[t]{3}{*}{ Lubricant ${ }^{a}$} & \multicolumn{2}{|c|}{ Temperature } & \multirow{2}{*}{\multicolumn{2}{|c|}{$\begin{array}{c}\text { Thermal } \\
\text { conductivity }\end{array}$}} & \multirow{2}{*}{\multicolumn{2}{|c|}{$\begin{array}{l}\text { Pressure- } \\
\text { viscosity } \\
\text { coefficient }\end{array}$}} & \multirow{2}{*}{\multicolumn{2}{|c|}{$\begin{array}{l}\text { Temperature- } \\
\text { viscosity } \\
\text { coefficient }\end{array}$}} & \multirow{2}{*}{\multicolumn{2}{|c|}{$\begin{array}{l}\text { Kinematic } \\
\text { viscosity }\end{array}$}} & \multirow{3}{*}{$\begin{array}{l}\text { Specific } \\
\text { gravity }\end{array}$} & \multirow{2}{*}{$\begin{array}{l}\text { Specific } \\
\text { heat }\end{array}$} \\
\hline & \multirow[t]{2}{*}{${ }^{\circ} \mathrm{C}$} & \multirow[t]{2}{*}{${ }^{\circ} \mathrm{F}$} & & & & & & & & & & \\
\hline & & & $\frac{w}{m^{\circ} \mathrm{C}}$ & $\frac{\mathrm{Btu}}{\mathrm{hr} \mathrm{ft}{ }^{\circ} \mathrm{F}}$ & $\frac{1}{\mathrm{GPa}}$ & $\frac{1}{p s i}$ & $\frac{1}{{ }^{\circ} \mathrm{C}}$ & $\frac{1}{\circ \mathrm{F}}$ & cSt & $\frac{\mathrm{ft}^{2}}{\mathrm{sec}}$ & & $\frac{\mathrm{Btu}}{\mathrm{lbm}{ }^{\circ} \mathrm{F}}$ or $\frac{\mathrm{mcal}}{\mathrm{mg}{ }^{\circ} \mathrm{C}}$ \\
\hline $\begin{array}{l}K \text { (turbine } \\
\text { engine oil) }\end{array}$ & $\begin{array}{r}40 \\
82 \\
100\end{array}$ & $\begin{array}{l}104.0 \\
179.6 \\
212.0\end{array}$ & $\begin{array}{r}0.115 \\
.115 \\
.115\end{array}$ & $\begin{array}{r}0.066 \\
.066 \\
.066\end{array}$ & $\frac{11.40}{-9.50}$ & $\frac{7.86 \times 10^{-5}}{6.55}$ & $\begin{array}{r}0.0223 \\
.0223 \\
.0223\end{array}$ & $\begin{array}{r}0.0124 \\
.0124 \\
.0124\end{array}$ & $\begin{array}{r}20.39 \\
7.61 \\
5.09\end{array}$ & $\begin{array}{l}28.39 \times 10^{-5} \\
8.19 \\
5.48\end{array}$ & $\begin{array}{r}0.9829 \\
.9721 \\
.9725\end{array}$ & $\begin{array}{l}0.464 \\
.495 \\
.507\end{array}$ \\
\hline $\begin{array}{l}\text { E (formulated } \\
\text { gear lubricant) }\end{array}$ & $\begin{array}{r}40 \\
82 \\
100\end{array}$ & $\begin{array}{l}104.0 \\
179.6 \\
212.0\end{array}$ & $\begin{array}{r}0.121 \\
.121 \\
.121\end{array}$ & $\begin{array}{r}0.070 \\
.070 \\
.070\end{array}$ & $\frac{15.53}{11.51}$ & $\frac{10.70 \times 10^{-5}}{7.94}$ & $\begin{array}{r}0.0232 \\
.0232 \\
.0232\end{array}$ & $\begin{array}{r}0.0129 \\
.0129 \\
.0129\end{array}$ & $\begin{array}{r}33.91 \\
8.91 \\
5.87\end{array}$ & $\begin{array}{l}36.50 \times 10-5 \\
9.59 \\
5.48\end{array}$ & $\begin{array}{r}0.9322 \\
.9211 \\
.9201\end{array}$ & $\begin{array}{r}0.680 \\
.730 \\
.767\end{array}$ \\
\hline
\end{tabular}

afrom ref. 1 


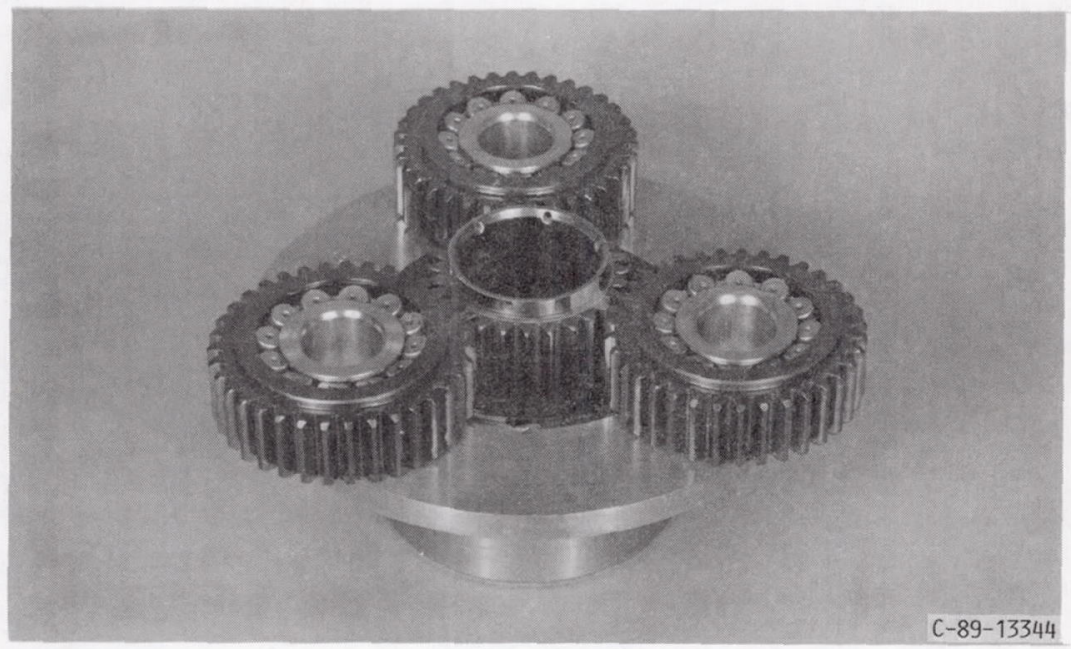

(a) 3 - PLANET STAGE

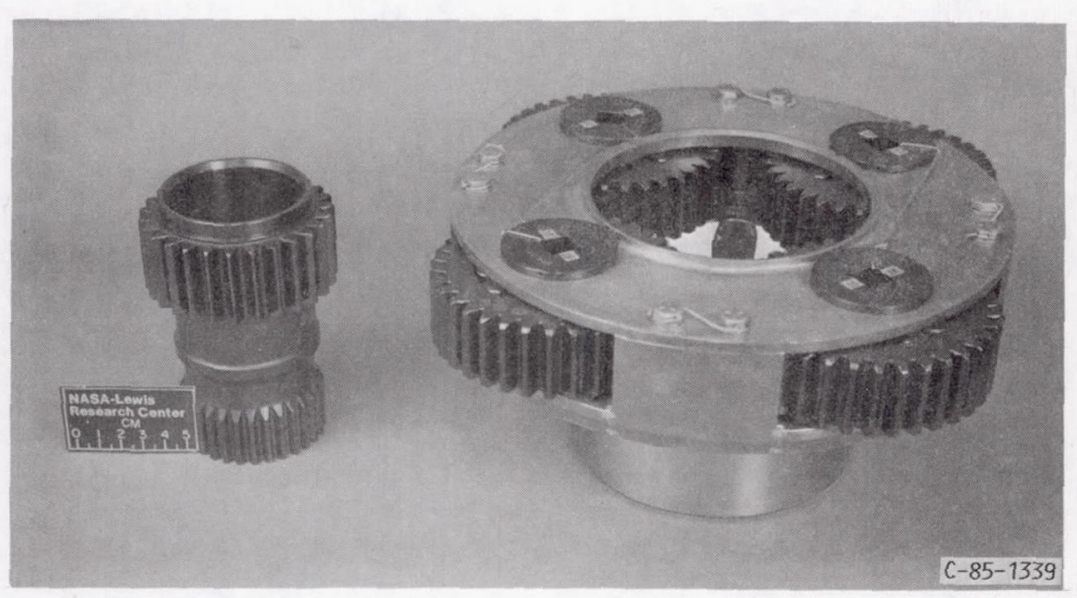

(b) 4 - PLANET STAGE

FIGURE 1. - SUNS, PLANETS, AND CARRIERS USED IN TEST PROGRAM. 

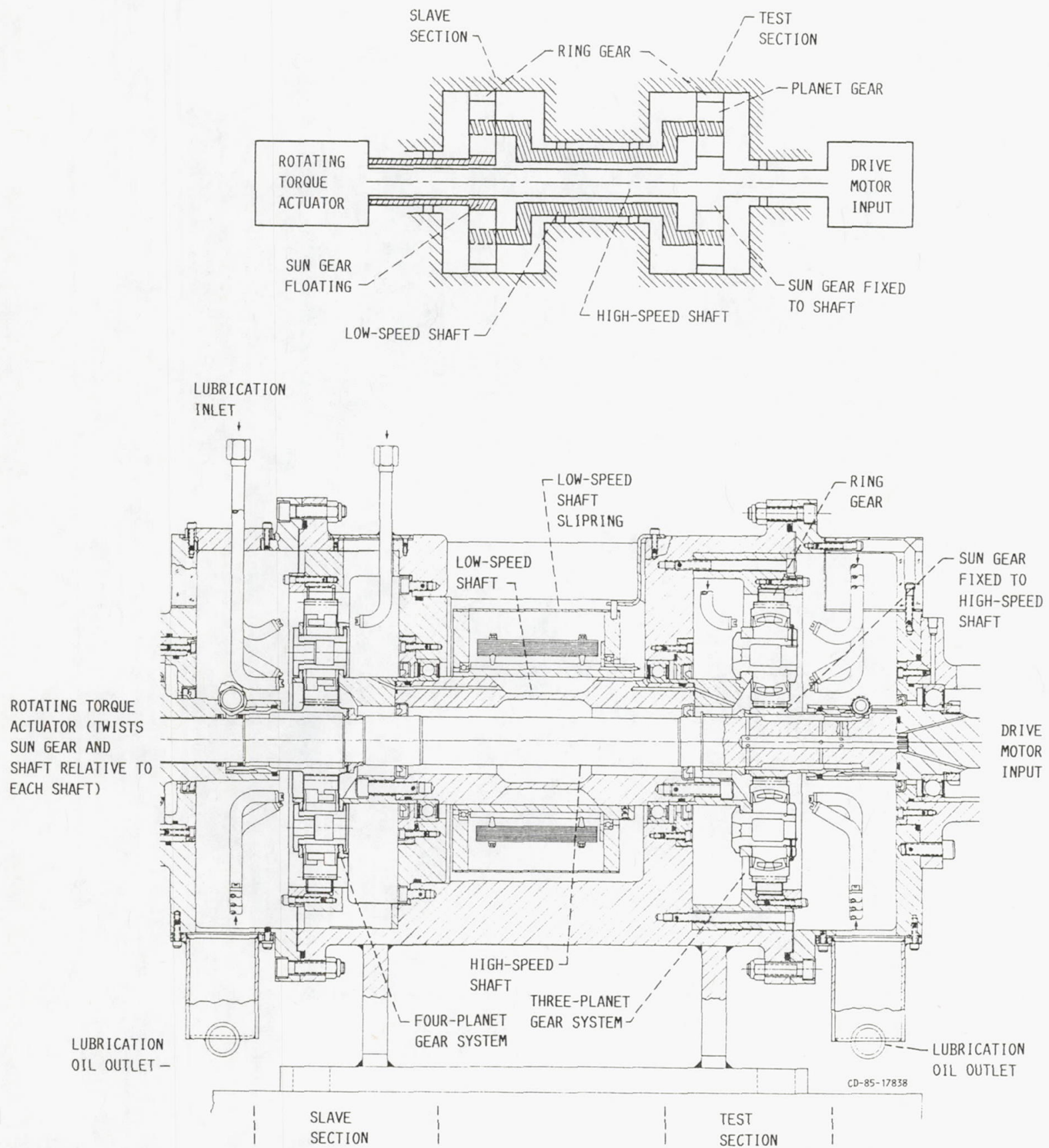

FIGURE 2. - CROSS-SECTIONAL VIEW OF TEST GEARBOX SHOWING KEY COMPONENTS. 


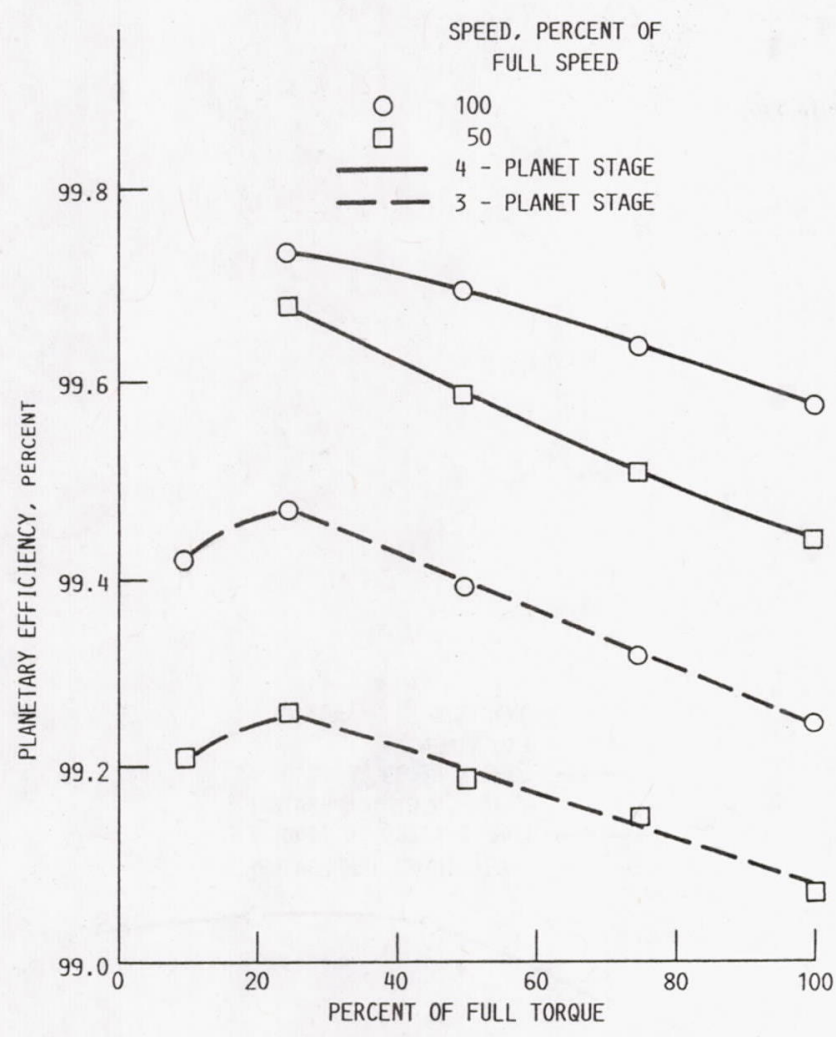

FIGURE 3. - PLANETARY EFFICIENCY AS A FUNCTION OF TORQUE AT TWO SPEEDS. LUBRICANT E; LUBRICANT INLET TEMPERATURE, $99{ }^{\circ} \mathrm{C}\left(210^{\circ} \mathrm{F}\right)$; FLOW RATE PER STAGE, $190 \mathrm{~cm}^{3} / \mathrm{SEC}$ (3.0 gpm).

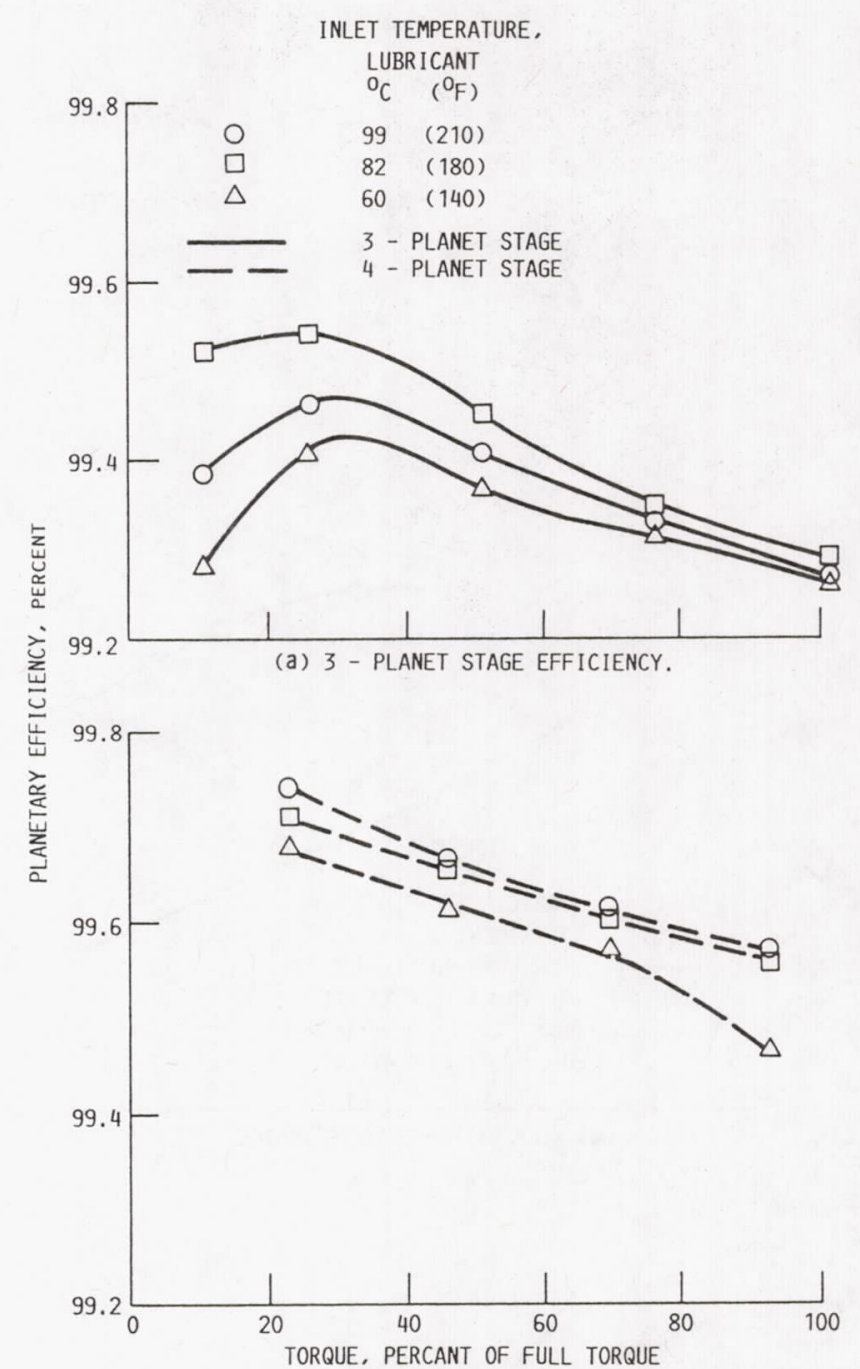

(b) 4 - PLANET STAGE EFFICIENCY.

FIGURE 4. - PLANETARY EFFICIENCY AS A FUNCTION OF TORQUE AT THREE OIL TEMPERATURES. LUBRICANT E: LUBRICANT FLOW PER STAGE, $190 \mathrm{~cm}^{3} / \mathrm{SEC}(3.0 \mathrm{gpm})$.

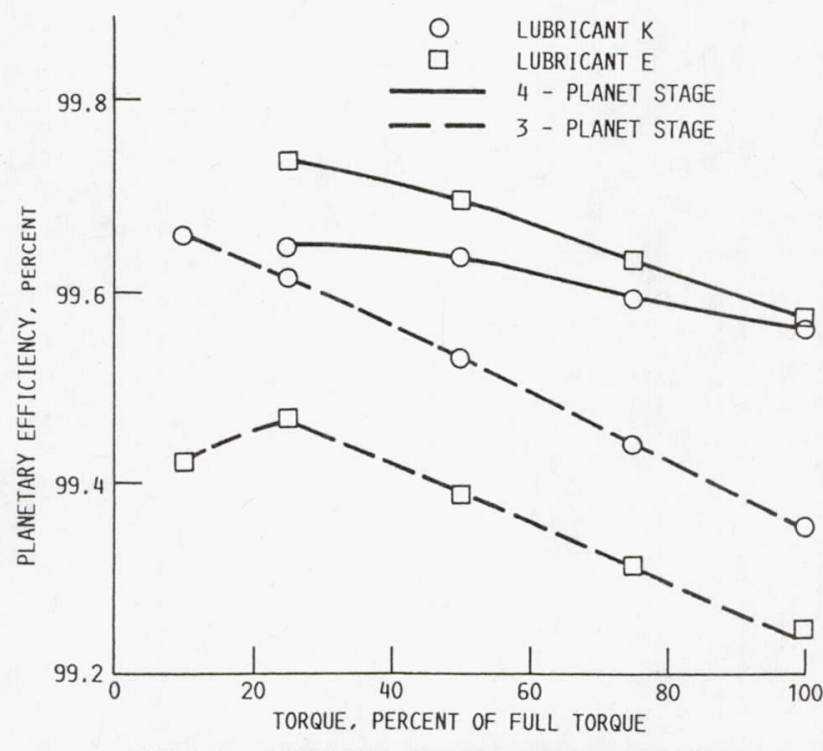

FIGURE 5. - COMPARISON OF EXPERIMENTAL RESULTS FOR TWO PLANETARY STAGES. SPEED 100 PERCENT; LUBRICANT INLET TEMERATURE, $99^{\circ} \mathrm{C}\left(210^{\circ} \mathrm{F}\right)$; LUBRICANT FLOW PER STAGE $190 \mathrm{~cm}^{3} / \mathrm{SEC}(3.0 \mathrm{gpm})$. 


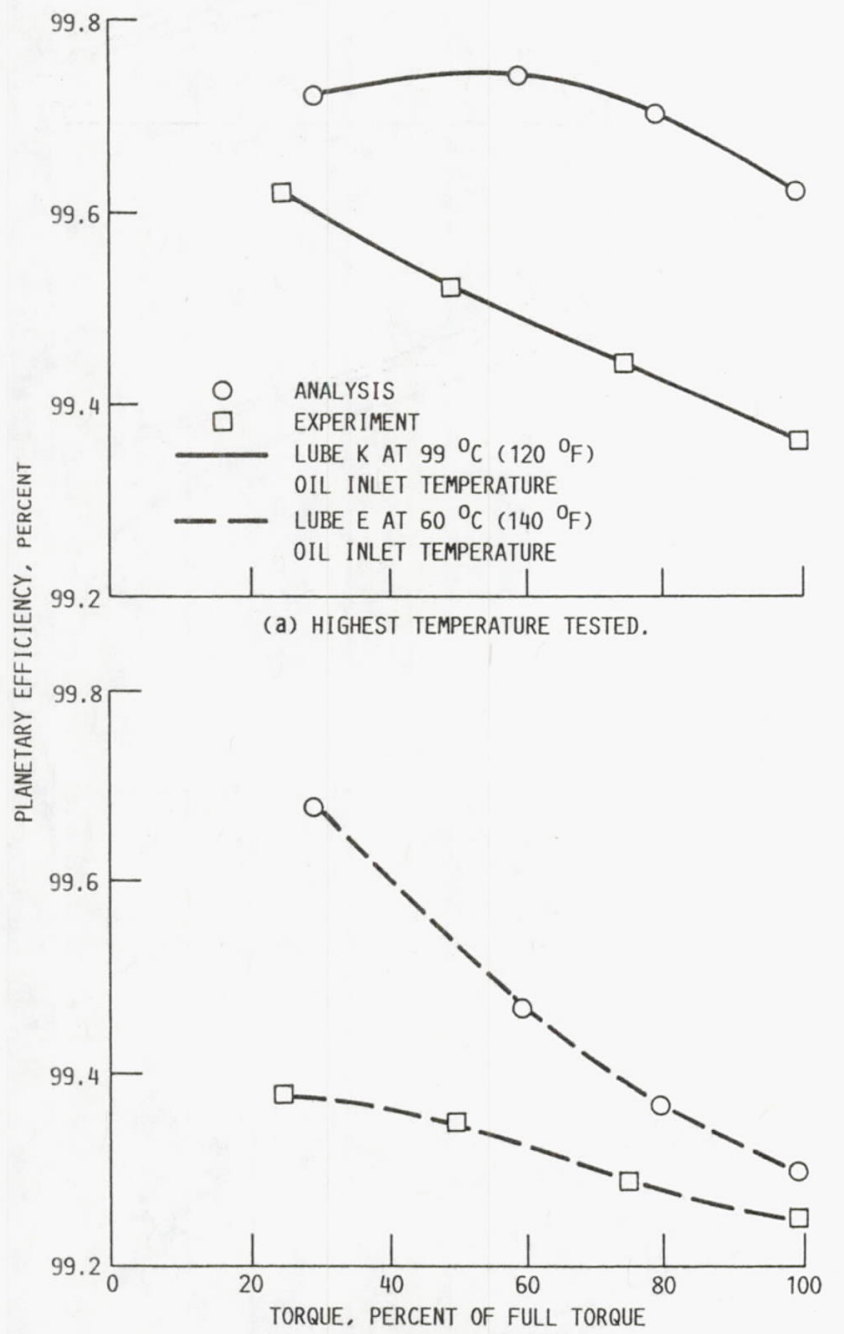

(b) LOWEST TEMPERATURE TESTED.

FIGURE 6. - COMPARISON OF ANALYSIS WITH EXPERIMENT FOR THREE PLANET STAGE. SPEED, 100 PERCENT; LUBERICANT FLOW RATE PER STAGE, $190 \mathrm{~cm}^{3} / \mathrm{SEC}(3.0 \mathrm{gpm})$.

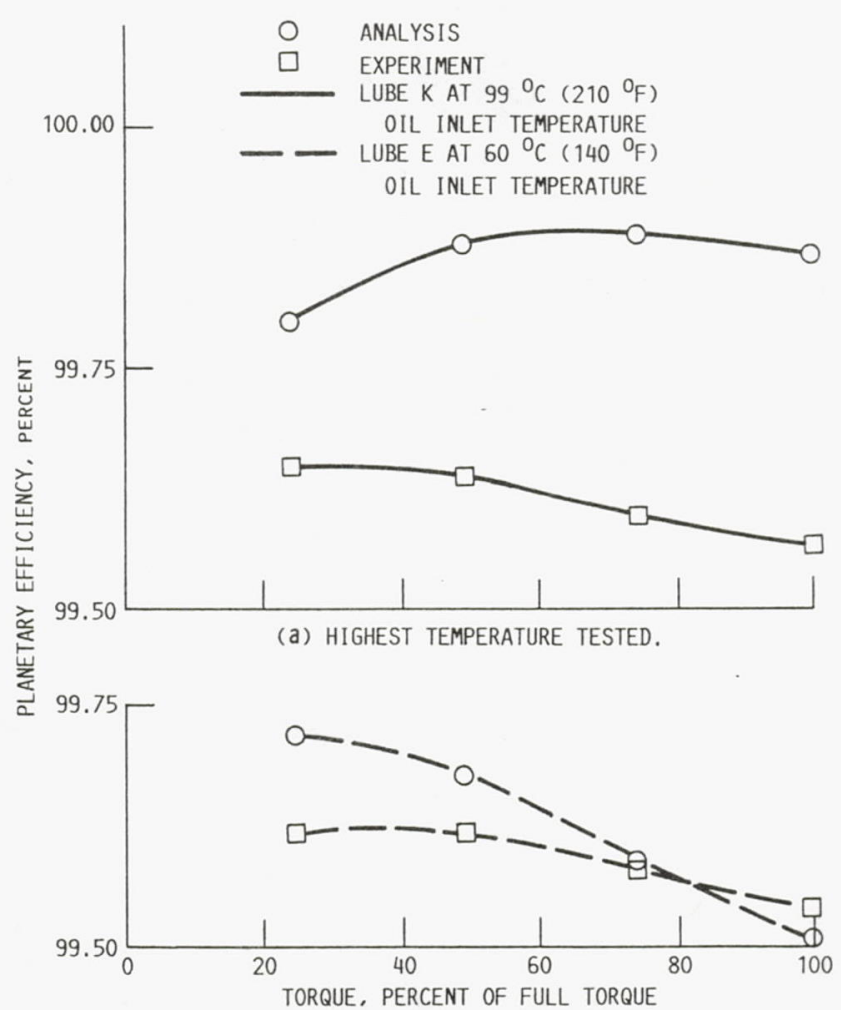

(b) LOWEST TEMPERATURE TESTED.

FIGURE 7. - COMPARISON OF ANALYSIS WITH EXPERIMENT FOR 4 - PLANET STAGE. SPEED, 100 PERCENT; LUBRICANT FLOW RATE PER STAGE, $190 \mathrm{~cm}^{3} / \mathrm{SEC}(3.0 \mathrm{gPm})$. 

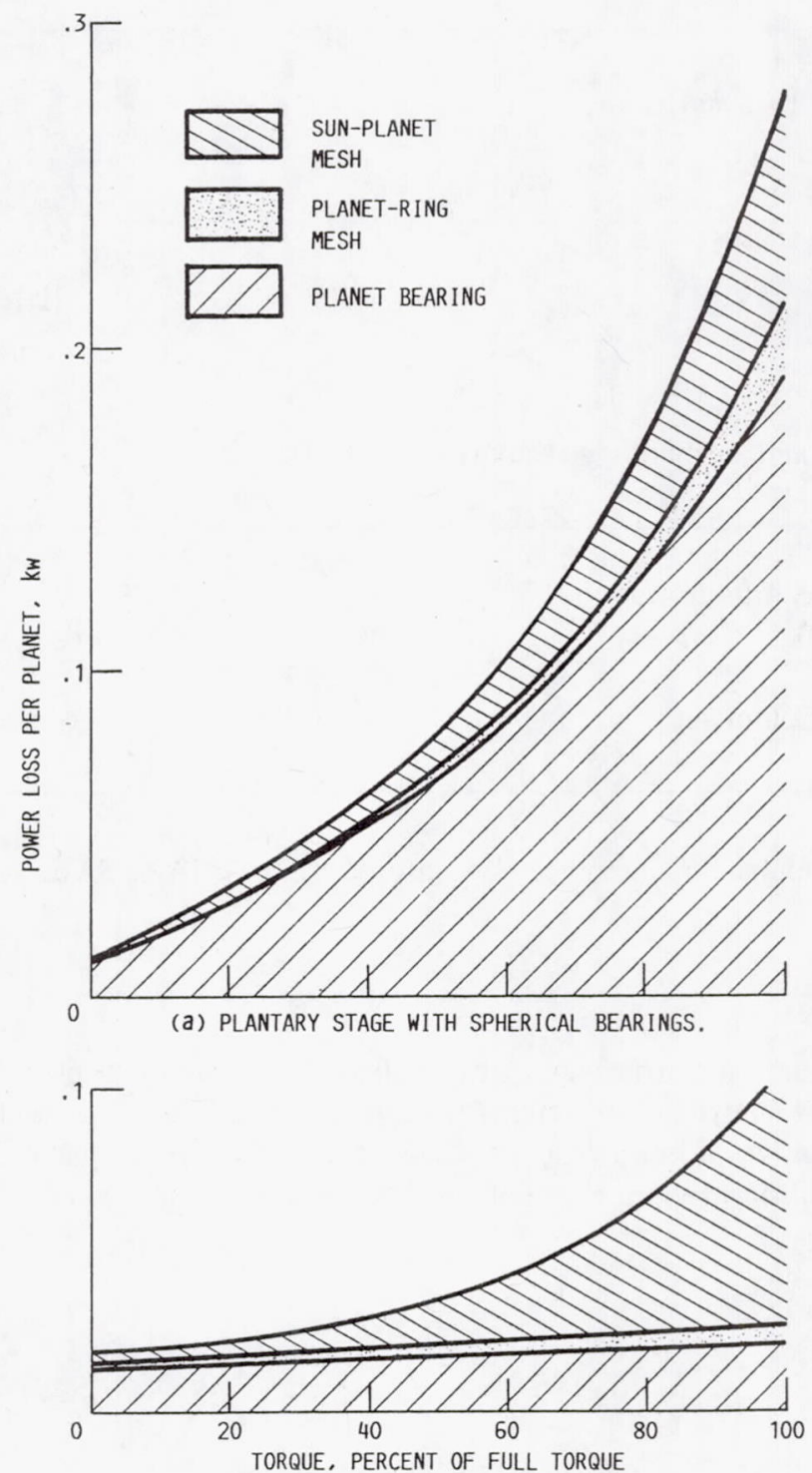

(b) PLANETARY STAGE WITH CYLINDRICAL BEARINGS.

FIGURE 8. - BREAKDOWN OF ANALYTICALLY PERDICTED POWER LOSS FOR TWO DESIGNS. 


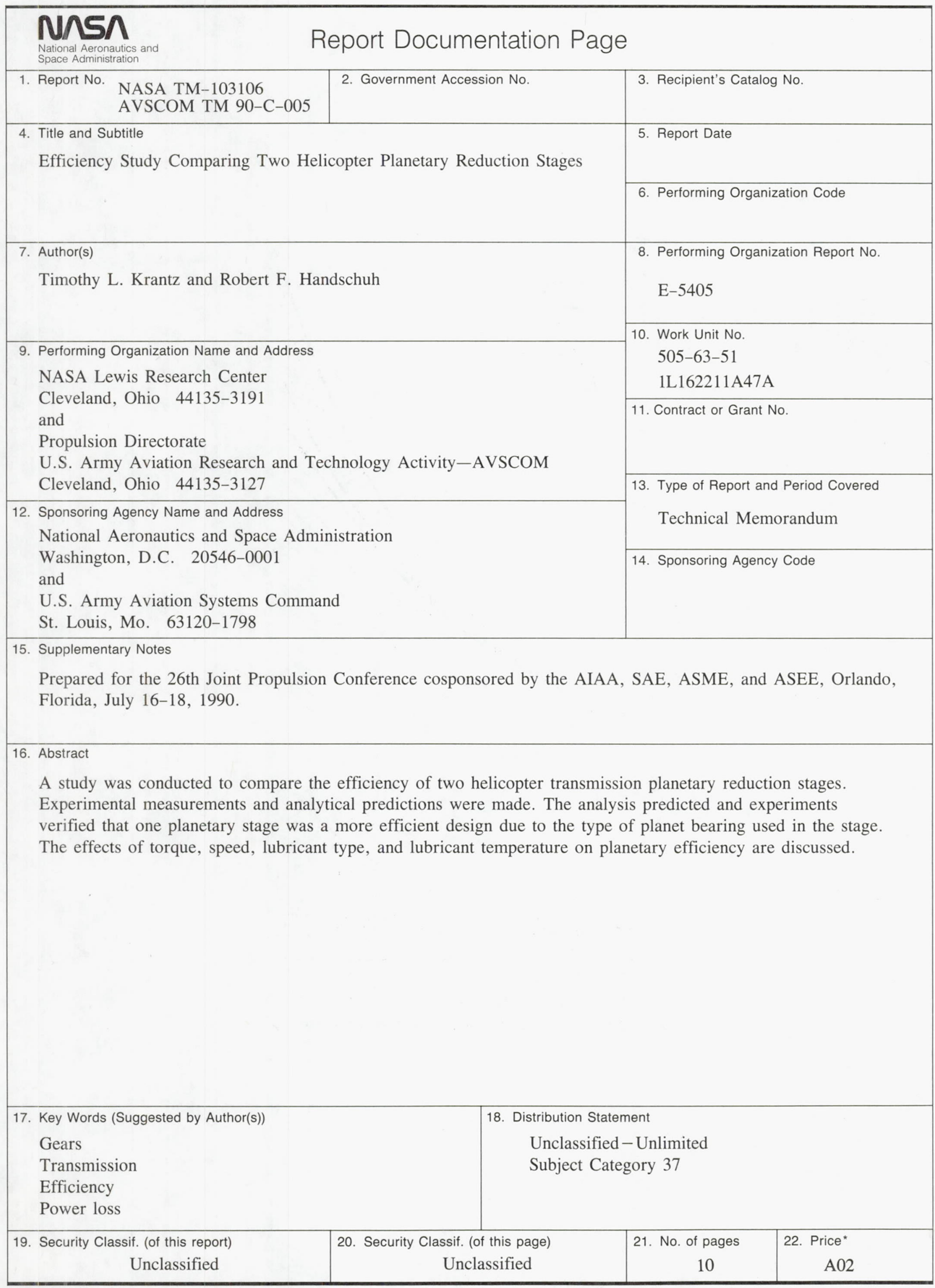

